\title{
Pathogenesis and Treatment of Pancreatic Cancer Related Pain
}

\author{
INES LOHSE ${ }^{1,2,3^{*}}$ and SHAUN P. BROTHERS ${ }^{1,2,3^{*}}$ \\ ${ }^{1}$ Center for Therapeutic Innovation, Miller School of Medicine, University of Miami, Miami, FL, U.S.A.; \\ ${ }^{2}$ Department of Psychiatry and Behavioral Sciences, \\ ${ }^{3}$ Molecular Therapeutics Shared Resource, Sylvester Comprehensive Cancer Center, University of Miami, FL, U.S.A.
}

\begin{abstract}
Pancreatic cancer is often diagnosed due to the patient seeking medical attention for abdominal pain. It is among the most painful cancers, with pain severity strongly correlating with prognosis. Perineural invasion is a prominent feature of pancreatic cancer and often the first route of metastasis resulting in neuropathic pain. While surgical pain is present, it is generally short-lived; chemo- and radio-therapy associated side effect pain is often longer lasting and more difficult to manage. Treatment-induced mucositis in response to chemotherapy occurs throughout the GI tract resulting in infection-prone ulcers on the lip, buccal mucosa, palate or tongue. Cisplatin treatment is associated with axonal neuropathy in the dorsal root ganglion, although other large sensory fibers can be affected. Opioid-induced hyperalgesia can also emerge in patients. Along with traditional means to address pain, neurolytic celiac plexus block of afferent nociceptive fibers has been reported to be effective in $74 \%$ of patients. Moreover, as cancer treatments become more effective and result in improved survival, treatment-related side effects become more prevalent. Here, pancreatic cancer and treatment associated pain are reviewed along with current treatment strategies. Potential future therapeutic strategies to target the pathophysiology underlying pancreatic cancer and pain induction are also presented.
\end{abstract}

Pancreatic cancer is the $2^{\text {nd }}$ most common cause of cancerrelated death, despite only being the 20th most common cancer

This article is freely accessible online.

*Both Authors contributed equally to this study.

Correspondence to: Shaun P. Brothers, University of Miami Miller School of Medicine, Center for Therapeutic Innovation, Department for Psychiatry and Behavioral Sciences, $1501 \mathrm{NW} 10^{\text {th }}$ Ave, BRB415, Miami, FL 33136, U.S.A. Tel: +1 3052436113, e-mail: sbrothers@med.miami.edu

Key Words: Pancreatic cancer, pain, cancer treatment-induced pain, pancreatic cancer treatment, pancreatic cancer pain. diagnosis. With the highest mortality rate among all major cancers, 5-year survival rates (Stage I 13\%, Stage II 6\% , Stage III 3\%, Stage IV 2\%) have not improved significantly over the past decade (1-3), even though extensive research efforts have uncovered new risk factors (4-9), genetic mutations $(8,10-18)$ and therapeutic options (19-26). Pancreatic cancer is generally a disease of older patients that is characterized by late diagnosis, rapid disease progression and resistance to chemotherapeutic treatments $(1,3)$. Often called the "silent killer", pancreatic cancer shows few to no symptoms in the early stages. When symptoms, specifically pain, are perceived by the patient they are vague and nonspecific often leading to late diagnosis and poor prognosis due to metastasis to surrounding organs (27-30). Studies have shown that the majority of pancreatic cancer patients, around $75 \%$, present with pain at the time of diagnosis although pain intensity varies depending on the site of distribution in the pancreas, anatomy and the presence of metastatic lesions or local invasion (28-32). Pain management is especially challenging, due to advanced patient age, the aggressive nature of the disease and the use of aggressive treatment regimen. Interestingly, the presence and severity of pain in pancreatic cancer patients correlates strongly with pancreatic cancer prognosis and an adverse tumor microenvironment, suggesting that a more toxic cancer environment correlates with increased nerve damage (29, 33-39).

Currently available pancreatic cancer treatments often exacerbate pain, and pain management strategies are almost exclusively opioid in nature, which not only have significant side effects, but do little to address the underlying causes. There is a specific, urgent need for better treatments for pain in pancreatic cancer patients.

\section{Pancreatic Cancer-induced Pain}

Pancreatic cancer patients typically suffer from high levels of abdominal pain symptoms that arise from a variety of causes including tissue damage, inflammation, ductal obstruction and infiltration, and can be visceral, somatic or neuropathic in origin (28-33). 
Somatic pain arises from local invasion and metastasis into the surrounding peritoneum, retroperitoneum, and bones, while visceral pain arises from the infiltration of adjacent organs, such as the liver and the accumulation of ascites in late stage patients (28-31). Specifically, pain resulting from metastasis to the liver and bile duct present problems due to high incidence rates in pancreatic cancer patients. Somatic pain signals are transmitted by the celiac plexus nerves (T12L1) via the sympathetic system through the splanchnic nerves (T5-T12) and to the central nervous system (40). Visceral pain is caused by damage to the upper abdominal viscera $(28,41)$. Nociceptive signals are carried along sympathetic fibers to the celiac plexus nerves and ganglia (T12-L2) and are transmitted through the splanchnic nerves (T5-T12) and to the higher centers of the central nervous system (40).

Perineural invasion is a prominent feature of pancreatic cancer and often the first route of metastasis $(28,31,33,41-$ 43). Extra-pancreatic nerve plexus invasion is responsible for the neuropathic pain sensation. Similarities in growth factor receptors and adhesion molecules between pancreatic cancer cells and neuronal cells, explain the affinity to neural tissue and lead to increased cancer cell proliferation, and migration and invasion along nerve bundles. Pancreatic cancer cell migration along nerve bundles results in neuropathic pain, increased neuroplasticity and pain sensation in response to growth stimulation of sensory fibers (34).

\section{Treatment-induced Pain}

Pancreatic cancer patients receive a number of invasive interventions as part of the cancer diagnosis and curative/palliative treatment approaches $(1,3)$, either as part of standard-of-care or as part of clinical trials. Novel therapeutic approaches or combination treatments are continuously evaluated pre-clinically and clinically in an effort to replace current treatment-induced toxicities $(37,38,44-51)$. Although the pain inflicted by cancer surgery or diagnostic procedures can be intense, these pain symptoms are generally short-lived and can be easily addressed pharmacologically in most cases $(32,52)$. Systemic side effects from treatment with chemotherapy, radiotherapy of the combination, such as bone marrow suppression, immunosuppression, nausea, vomiting, diarrhea, fever, anorexia, asthenia, cachexia, cardiovascular, renal and hepatic toxicity, alopecia, sloughing of skin and mucosal membranes, as well as central and peripheral neuropathic toxicities, however, can persist throughout the treatment and are not easily addressed without treatment interruption (52-55).

Cancer treatments have become significantly more effective over the last decade resulting in longer patient survival, which also makes treatment-related side effects more prevalent. Specifically, peripheral neuropathic pain and mucositis are common and very painful side effects of a number of chemotherapeutics (cisplatin, fluorouracil, neurotoxic chemotherapy) and radiation and can be doselimiting (52-57).

In pancreatic cancer, treatment-induced mucositis is common in response to treatment with standard-of-care (cisplatin, 5-FU, taxanes), and occurs throughout the GI tract (esophagus, small and large intestine) (56, 58-60). The most prominent symptoms are observed in the oral mucosa with ulcers on the lip, buccal mucosa, palate or tongue. The initial inflammation is followed by secondary bacterial, yeast (thrush) and/or viral infections. Initial symptoms often manifest toward the end or after completion of the treatment cycle and can persist for weeks depending on the treatment regimen $(53,54,59,61)$. Additional side effects are malnutrition and weight loss.

Chemotherapy-induced neuropathic pain is commonly observed in cancer patients in response to a variety of chemotherapeutic drugs $(52,55,59,62)$. In pancreatic cancer specifically, cisplatin treatment is associated with axonal neuropathy in the dorsal root ganglion, although other large sensory fibers can be affected. Similar results have been observed in response to treatment with oxaliplatin $(55,63,64)$. Gemcitabine and taxanes are also associated with a spectrum of neuropathies. Gemcitabine-induced neuropathies range from mild paresthesia to severe peripheral and autonomic neuropathy $(55,62,64)$. Taxanes induce neuropathic symptoms such as peripheral burning-like sensations and numbness, paclitaxel-associated acute pain syndrome, motor neuropathies and autonomic neuropathy. These symptoms are dose-dependent and must be weighed against the potential for therapeutic benefit. Most patients receive combinations of these drugs as part of their anti-cancer therapy, which can lead to synergistic neurotoxicity $(55,62)$.

Because pancreatic cancer patients display high levels of cancer-associated pain prior to therapy, treatment-related pain is often difficult to distinguish and may make a relatively minor contribution to the overall pain (30).

\section{Current Clinical Pain Management}

The majority of pancreatic cancer patients present with moderate to severe pain at the time of diagnosis, making pain management a priority in patient treatment $(32,65,66)$. Due to the aggressive nature of pancreatic cancer, however, increasing levels of pain can be challenging to address. Pancreatic cancer-related pain is typically addressed pharmaceutically using analgesics, opioids and antiinflammatory drugs, each of which can be associated with severe side effects (67-69). Nevertheless, the majority of cancer pain and treatment-induced pain can be addressed using the three-tier WHO analgesic ladder where mild analgesics are prioritized unless they are unable to address 
the pain state, followed by progressively stronger agents and combinations $(32,66,70)$. The first line treatment for pancreatic cancer pain is usually a mid-tier opioid-based pharmacotherapy aiming to control pain symptoms while minimizing opioid side-effects $(71,72)$. Nevertheless, individual pain and opioid tolerance require patient-specific drug selection, consideration of route, individualization of the dose and common side effect management. Adjuvant analgesics, such as glucocorticoids, antidepressants and anticonvulsants, can be helpful when opioid treatment alone is not successful.

Opioid-induced hyperalgesia (OIH) can emerge in patients, and is likely to increase in prevalence alongside successful cancer treatment. OIH is a condition in which the opioid therapy prescribed to relieve pain results in a paradoxical worsening of the pain symptoms (73). CNS adaptation to opiates can result in hyper-sensitization to pain signals, especially when opiates are discontinued (74). Opiates can also induce inflammation, which can exacerbate pain and contribute to $\mathrm{OIH}$. While discontinuing the opioid or providing mu opioid receptor antagonists are treatment options, this is not always possible in pancreatic cancer patients. In this case, opioid reduction or a switch to buprenorphine or a different structural class of opioids is warranted.

Surgeries removing the tumor (Whipple surgery, distal or total pancreatectomy) can alleviate tumor-induced pain while increasing patient survival (26). Unfortunately, only $20 \%$ of all patients qualify for surgery at the time of diagnosis (25, 35 ). In cases of locally advanced tumors presenting with pain symptoms associated with blockage of the small intestine or bile accumulation, biliary or gastric bypass surgery are used to reduce pain symptoms (35).

Neurolytic celiac plexus block (NCPB) of afferent nociceptive fibers as a means to relieve visceral cancerrelated pain using ethanol has been reported to be effective in $74 \%$ of patients. CPB can also result in reduced need for opiate analgesics $(27,75-79)$. However, this method has some undesirable side effects such as induction of back pain and orthostatic hypertension $(75,76)$. Less frequent, though more serious, other side effects can also occur such as spinal cord injury due to spinal ischemia, among others.

A study conducted by Wong et al. analyzed the effect the neurolytic celiac plexus block (NCPB) and opioids alone, on pain relief, quality of life and survival rate in patients with inoperable pancreatic cancer (80). Results show that both treatments improve quality of life and pain intensity within the first week of administration, however, a larger decrease in pain has been observed for the NCPB group, improving their quality of life. Nerve block treatment is preferred when opioid medication results in unmanageable side effects and high pain levels. Additionally, NPCB increased 1-year survival compared to the opioids alone (16\% vs. 6\%). Overall survival, however, was not affected by either method
(80). The combination of CPB and pancreas cryoablation (PCA) has been shown to effectively alleviate cancer pain for more than 8 weeks without severe side effects (81).

Cannabinoids, such as dronabinol and nabilone, are approved drugs for the symptomatic treatment of cancerrelated side effects (82). Cannabinoids reduce pain symptoms through supraspinal, spinal, and peripheral modes of action and can be used to alleviate both caner- and treatment-induced pain states $(63,83,84)$. Additionally, cannabinoid treatment can address the cause of pain by reducing the release of inflammatory signals and increasing endogenous opioid release through the CB2 receptors, affecting mast cell receptors and keratinocytes $(83,84)$. CB1 receptor is the nervous system target of cannabinoids and is found in both the central nervous system (CNS) and in peripheral nerve terminals, and high receptor concentrations in brain regions regulate nociceptive processing $(83,84)$. Clinically, cannabinoids are mainly used as supportive therapy to reduce pain, improve sleep and the nutritional state of pancreatic cancer patients (85).

Other treatments involve electro-acupuncture or hypnosis (86-89). Although treatment outcome and pain relief differ dramatically between patients, positive results have been observed in some patients (88). Additional follow-up of these results is required before broad implementation and replacement of more proven methods, however, given the complete lack of adverse side effects, these can be considered as adjuvant therapies without significant potential for causing harm.

\section{Future Outlook}

Pain, whether neuropathic, inflammatory or visceral in nature, results in a large number of molecular and cellular adaptations in the affected tissue and nervous system, all of which contribute to the development of chronic pain symptoms. A number of studies have provided evidence that tissue damage, as found in cancer patients, induces significant changes in chromatin structure leading to changes in local gene expression and neve function (90-92). These epigenetic changes may contribute to the development of several pain symptoms and the manifestation of chronic pain. In addition to providing a valuable insight into the molecular mechanisms of pain development and chronic pain syndromes, some studies have provided evidence regarding the use of epigenetic modulation as a potential therapeutic option for cancer-related pain $(91,93,94)$.

Epigenetic enzymes such as histone acetylases (HATs) and histone deacetylases (HDACs) are fundamental regulators of gene expression that act by regulating chromatin conformation through changes in the acetylation status of histone proteins. Cancer treatment has been the primary target of HDAC inhibitor development due to their ability to reduce tumor 
Table I. Pain treatments in pancreatic cancer

\begin{tabular}{|c|c|c|c|}
\hline Treatment approaches & Medications and modalities & Administration route/techniques & Indications \\
\hline \multirow[t]{6}{*}{ Pharmaceutical } & Opioids and derivates & Oral & Moderate to severe pain \\
\hline & & Subcutaneous & Impossible oral intake (occlusion) \\
\hline & & Patch (fentanyl) & Breakthrough pain \\
\hline & & Nasal & Breakthrough pain \\
\hline & Antiepileptics & Oral & Neuropathic pain \\
\hline & Corticosteroids & Oral or IV & Adjuvant (metastatic bone pain) \\
\hline \multirow[t]{3}{*}{ Interventional } & $\begin{array}{l}\text { Celiac plexus block (LA) } \\
\text { or neuolysis }\end{array}$ & $\begin{array}{l}\text { Transcutaneous guidance }{ }^{1} \text { or } \\
\text { endoscopic ultrasonography }\end{array}$ & Refractory pain \\
\hline & Splanchnicectomy & Thoracotomy, Thoracoscopy & Intractable pain \\
\hline & Intrathecal therapy & Implantable intrathecal drug delivery systems & Palliative \\
\hline \multirow[t]{2}{*}{ Alternative medicine } & Acupuncture & Jiaji points & Adjuvant, interventional \\
\hline & Hypnosis & Hypnosis expert & Any stage of pain \\
\hline
\end{tabular}

${ }^{1}$ Ultrasound, X-ray fluoroscopy or computed tomography; IV: intravenous.

growth. Nevertheless, recent studies have shown that HDAC inhibitors can reduce inflammatory and neuropathic pain in nociceptive animal models and models of traumatic and druginduced peripheral neuropathy $(92,95)$. HDAC inhibitors selective for class I and II HDAC enzymes delayed the onset and reduced pain behavior, formalin-induced inflammation and stress-induced visceral nociception (92). Chronic pain is induced by dysregulation of GABA-mediated antinociception and is associated with hypoacetylation and decreased expression of glutamate decarboxylase 2. GABA-mediated synaptic function was restored in response to treatment with HDAC inhibitors, resulting in a reduction in neuropathic pain and mechanical hyperalgesia (92).

\section{Conclusion}

Pancreatic cancer is notable for its late diagnosis, poor prognosis and debilitating abdominal and back pain. Clinical pain management remains challenging, specifically in the light of the aggressive therapeutic interventions used in pancreatic cancer treatment that further add to the cancer-induced pain symptoms. While a number of pharmacological and interventional treatment options exist for pancreatic cancer patients, the absence of specific treatment guidelines and side effects associated with available treatments limit pain management options for effective pancreatic cancer pain treatment (Table I). Recent studies have implicated modifications of the epigenome in the development of acute pain symptoms and chronic pain conditions and suggested that epigenetic modulation may provide a novel route for pain management in pancreatic cancer.

\section{Conflicts of Interest}

The Authors have no conflict of interest to report regarding this study.

\section{Author's Contributions}

IL and SPB both contributed to the writing of the manuscript.

\section{Acknowledgements}

This work is dedicated to the memory of Michael Leitl, Ph.D.

\section{Funding}

SPB receives support from the National Institutes of Health (R01NS092671 and R01MH110441), the University of Miami Sylvester Comprehensive Cancer Center Molecular Therapeutics Shared Resource (MTSR), the Jay Weiss Institute for Health Equity and the Ryan Foundation.

\section{References}

1 American Cancer Society: Cancer facts \& figures 2019.

2 Jemal A, Bray F, Center MM, Ferlay J, Ward E and Forman D: Global cancer statistics. CA Cancer J Clin 61(2): 69-90, 2011. PMID: 21296855. DOI: 10.3322/caac.20107

3 Seufferlein T, Bachet JB, Van Cutsem E, Rougier P and Group EGW: Pancreatic adenocarcinoma: Esmo-esdo clinical practice guidelines for diagnosis, treatment and follow-up. Ann Oncol 23(Suppl 7): vii33-40, 2012. PMID: 22997452. DOI: 10.1093/ annonc/mds224

4 Jiao L, Mitrou PN, Reedy J, Graubard BI, Hollenbeck AR, Schatzkin A and Stolzenberg-Solomon R: A combined healthy lifestyle score and risk of pancreatic cancer in a large cohort study. Arch Intern Med 169(8): 764-770, 2009. PMID: 19398688. DOI: 10.1001/archinternmed.2009.46

5 Alsamarrai A, Das SL, Windsor JA and Petrov MS: Factors that affect risk for pancreatic disease in the general population: A systematic review and meta-analysis of prospective cohort studies. Clin Gastroenterol Hepatol 12(10): 1635-1644 e1635; quiz e1103, 2014. PMID: 24509242. DOI:10.1016/j.cgh.2014.01.038

6 Zheng J, Guinter MA, Merchant AT, Wirth MD, Zhang J, Stolzenberg-Solomon RZ and Steck SE: Dietary patterns and 
risk of pancreatic cancer: A systematic review. Nutr Rev 75(11): 883-908, 2017. PMID: 29025004. DOI: 10.1093/nutrit/nux038

7 Kirkegard J, Mortensen FV and Cronin-Fenton D: Chronic pancreatitis and pancreatic cancer risk: A systematic review and meta-analysis. Am J Gastroenterol 112(9): 1366-1372, 2017. PMID: 28762376. DOI: 10.1038/ajg.2017.218

8 Collins MA, Bednar F, Zhang Y, Brisset JC, Galban S, Galban CJ, Rakshit S, Flannagan KS, Adsay NV and Pasca di Magliano $\mathrm{M}$ : Oncogenic kras is required for both the initiation and maintenance of pancreatic cancer in mice. J Clin Invest 122(2): 639-653, 2012. PMID: 22232209. DOI: 10.1172/JCI59227

9 Larsson SC, Permert J, Hakansson N, Naslund I, Bergkvist L and Wolk A: Overall obesity, abdominal adiposity, diabetes and cigarette smoking in relation to the risk of pancreatic cancer in two swedish population-based cohorts. Br J Cancer 93(11): 1310-1315, 2005. PMID: 16288300. DOI: 10.1038/sj.bjc. 6602868

10 Singhal M, Khatibeghdami M, Principe DR, Mancinelli GE, Schachtschneider KM, Schook LB, Grippo PJ and Grimaldo SR: Tm4sf18 is aberrantly expressed in pancreatic cancer and regulates cell growth. PLoS One 14(3): e0211711, 2019. PMID: 30897168. DOI: 10.1371/journal.pone.0211711

11 Thibodeau ML, Zhao EY, Reisle C, Ch'ng C, Wong HL, Shen Y, Jones MR, Lim HJ, Young S, Cremin C, Zhang W, Holt R, Eirew P, Karasinska J, Kalloger S, Taylor G, Majounie E, Bonakdar M, Zong Z, Bleile D, Chiu R, Birol I, Gelmon K, Lohrisch C, Mungall KL, Mungall AJ, Moore R, Ma YP, Fok A, Yip S, Karsan A, Huntsman D, Schaeffer DF, Laskin J, Marra MA, Renouf DJ, Jones SJM and Schrader KA: Base excision repair deficiency signatures implicate germline and somatic mutyh aberrations in pancreatic ductal adenocarcinoma and breast cancer oncogenesis. Cold Spring Harb Mol Case Stud, 2019. PMID: 30833417. DOI: $10.1101 / \mathrm{mcs} . a 003681$

12 Gill P, Kim E, Chua TC, Clifton-Bligh RJ, Nahm CB, Mittal A, Gill AJ and Samra JS: Mirna-3653 is a potential tissue biomarker for increased metastatic risk in pancreatic neuroendocrine tumours. Endocr Pathol, 2019. PMID: 30767148. DOI: 10.1007/s12022-019-9570-y

13 Liu Y, Zhu D, Xing H, Hou Y and Sun Y: A 6gene risk score system constructed for predicting the clinical prognosis of pancreatic adenocarcinoma patients. Oncol Rep 41(3): 15211530, 2019. PMID: 30747226. DOI: 10.3892/or.2019.6979

14 Wu J, Liu J, Wei X, Yu Q, Niu X, Tang S and Song L: A featurebased analysis identifies colla2 as a regulator in pancreatic cancer. J Enzyme Inhib Med Chem 34(1): 420-428, 2019. PMID: 30734598. DOI: 10.1080/14756366.2018.1484734

15 Murakawa M, Aoyama T, Miyagi Y, Kobayashi S, Ueno M, Morimoto M, Numata M, Yamamoto N, Tamagawa H, Yukawa N, Rino Y, Masuda M and Morinaga S: The impact of sparc expression on the survival of pancreatic ductal adenocarcinoma patients after curative resection. J Cancer 10(3): 627-633, 2019. PMID: 30719160. DOI: 10.7150/jca.28660

16 Malsy M, Graf B and Almstedt K: The active role of the transcription factor $\mathrm{sp} 1$ in nfatc2-mediated gene regulation in pancreatic cancer. BMC Biochem 20(1): 2, 2019. PMID: 30696421. DOI: 10.1186/s12858-019-0105-4

17 Obazee O, Archibugi L, Andriulli A, Soucek P, Malecka-Panas E, Ivanauskas A, Johnson T, Gazouli M, Pausch T, Lawlor RT, Cavestro GM, Milanetto AC, Di Leo M, Pasquali C, Hegyi P, Szentesi A, Radu CE, Gheorghe C, Theodoropoulos GE,
Bergmann F, Brenner H, Vodickova L, Katzke V, Campa D, Strobel O, Kaiser J, Pezzilli R, Federici F, MohelnikovaDuchonova B, Boggi U, Lemstrova R, Johansen JS, Bojesen SE, Chen I, Jensen BV, Capurso G, Pazienza V, Dervenis C, Sperti C, Mambrini A, Hackert T, Kaaks R, Basso D, TalarWojnarowska R, Maiello E, Izbicki JR, Cuk K, Saum KU, Cantore M, Kupcinskas J, Palmieri O, Delle Fave G, Landi S, Salvia R, Fogar P, Vashist YK, Scarpa A, Vodicka P, Tjaden C, Iskierka-Jazdzewska E and Canzian F: Germline brca2 k3326x and chek $2 \mathrm{i} 157 \mathrm{t}$ mutations increase risk for sporadic pancreatic ductal adenocarcinoma. Int J Cancer, 2019. PMID: 30672594. DOI: $10.1002 /$ ijc. 32127

18 Wood LD, Yurgelun MB and Goggins MG: Genetics of familial and sporadic pancreatic cancer. Gastroenterology, 2019. PMID: 30660730. DOI: 10.1053/j.gastro.2018.12.039

19 Bryant KL, Stalnecker CA, Zeitouni D, Klomp JE, Peng S, Tikunov AP, Gunda V, Pierobon M, Waters AM, George SD, Tomar G, Papke B, Hobbs GA, Yan L, Hayes TK, Diehl JN, Goode GD, Chaika NV, Wang Y, Zhang GF, Witkiewicz AK, Knudsen ES, Petricoin EF, 3rd, Singh PK, Macdonald JM, Tran NL, Lyssiotis CA, Ying H, Kimmelman AC, Cox AD and Der CJ: Combination of erk and autophagy inhibition as a treatment approach for pancreatic cancer. Nat Med, 2019. PMID: 30833752. DOI: 10.1038/s41591-019-0368-8

20 Gurbuz N and Ozpolat B: Microrna-based targeted therapeutics in pancreatic cancer. Anticancer Res 39(2): 529-532, 2019. PMID: 30711926. DOI: 10.21873/anticanres.13144

21 Bertholet J, Hunt A, Dunlop A, Bird T, Mitchell RA, Oelfke U, Nill S and Aitken K: Comparison of the dose escalation potential for two hypofractionated radiotherapy regimens for locally advanced pancreatic cancer. Clin Transl Radiat Oncol 16(21-27, 2019. PMID: 30911688. DOI: 10.1016/j.ctro.2019.03.001

22 Flak RV, Stender MT, Jensen TM, Andersen KL, Henriksen SD, Mortensen PB, Sall M and Thorlacius-Ussing O: Treatment of locally advanced pancreatic cancer with irreversible electroporation - a danish single center study of safety and feasibility. Scand J Gastroenterol: 1-7, 2019. PMID: 30907286. DOI: 10.1080/00365521.2019.1575465

23 Haney SL, Varney ML, Chhonker YS, Shin S, Mehla K, Crawford AJ, Smith HJ, Smith LM, Murry DJ, Hollingsworth MA and Holstein SA: Inhibition of geranylgeranyl diphosphate synthase is a novel therapeutic strategy for pancreatic ductal adenocarcinoma. Oncogene, 2019. PMID: 30918331. DOI: 10.1038/s41388-019-0794-6

24 Ray P, Nair G, Ghosh A, Banerjee S, Golovko MY, Banerjee SK, Reindl KM, Mallik S and Quadir M: Microenvironment-sensing, nanocarrier-mediated delivery of combination chemotherapy for pancreatic cancer. J Cell Commun Signal, 2019. PMID: 30915617. DOI: 10.1007/s12079-019-00514-w

25 Paulson AS, Tran Cao HS, Tempero MA and Lowy AM: Therapeutic advances in pancreatic cancer. Gastroenterology 144(6): 1316-1326, 2013. PMID: 23622141. DOI: 10.1053/j.gastro. 2013.01.078

26 Nienhuijs SW, van den Akker SA, de Vries E, de Hingh IH, Visser $\mathrm{O}$ and Lemmens VE: Nationwide improvement of only short-term survival after resection for pancreatic cancer in the netherlands. Pancreas 41(7): 1063-1066, 2012. PMID: 22617713. DOI: 10.1097/MPA.0b013e31824c3dbf

27 Cornman-Homonoff J, Holzwanger DJ, Lee KS, Madoff DC and Li D: Celiac plexus block and neurolysis in the management of 
chronic upper abdominal pain. Semin Intervent Radiol 34(4): 376-386, 2017. PMID: 29249862. DOI: 10.1055/s-0037-1608861

28 Bapat AA, Hostetter G, Von Hoff DD and Han H: Perineural invasion and associated pain in pancreatic cancer. Nat Rev Cancer 11(10): 695-707, 2011. PMID: 21941281. DOI: $10.1038 / \mathrm{nrc} 3131$

29 di Mola FF and di Sebastiano P: Pain and pain generation in pancreatic cancer. Langenbecks Arch Surg 393(6): 919-922, 2008. PMID: 18193269. DOI: 10.1007/s00423-007-0277-z

30 D'Haese JG, Hartel M, Demir IE, Hinz U, Bergmann F, Buchler MW, Friess $\mathrm{H}$ and Ceyhan GO: Pain sensation in pancreatic diseases is not uniform: The different facets of pancreatic pain. World J Gastroenterol 20(27): 9154-9161, 2014. PMID: 25083089. DOI: 10.3748/wjg.v20.i27.9154

31 Pour PM, Bell RH and Batra SK: Neural invasion in the staging of pancreatic cancer. Pancreas 26(4): 322-325, 2003. PMID: 12717262. DOI: 10.1097/00006676-200305000-00002

32 Hameed M, Hameed $\mathrm{H}$ and Erdek M: Pain management in pancreatic cancer. Cancers (Basel) 3(1): 43-60, 2010. PMID: 24212605. DOI: $10.3390 /$ cancers 3010043

33 Lindsay TH, Jonas BM, Sevcik MA, Kubota K, Halvorson KG, Ghilardi JR, Kuskowski MA, Stelow EB, Mukherjee P, Gendler SJ, Wong GY and Mantyh PW: Pancreatic cancer pain and its correlation with changes in tumor vasculature, macrophage infiltration, neuronal innervation, body weight and disease progression. Pain 119(1-3): 233-246, 2005. PMID: 16298491. DOI: $10.1016 /$ j.pain.2005.10.019

34 Ceyhan GO, Bergmann F, Kadihasanoglu M, Altintas B, Demir IE, Hinz U, Muller MW, Giese T, Buchler MW, Giese NA and Friess H: Pancreatic neuropathy and neuropathic pain - a comprehensive pathomorphological study of 546 cases. Gastroenterology 136(1): 177-186 e171, 2009. PMID: 18992743. DOI: $10.1053 /$ j.gastro.2008.09.029

35 Muller MW, Friess H, Koninger J, Martin D, Wente MN, Hinz U, Ceyhan GO, Blaha $\mathrm{P}$, Kleeff $\mathrm{J}$ and Buchler MW: Factors influencing survival after bypass procedures in patients with advanced pancreatic adenocarcinomas. Am J Surg 195(2): 221-228, 2008. PMID: 18154768. DOI: 10.1016/j.amjsurg.2007.02.026

36 Chee NT, Lohse I and Brothers SP: Mrna-to-protein translation in hypoxia. Mol Cancer 18(1): 49, 2019. PMID: 30925920. DOI: 10.1186/s12943-019-0968-4

37 Lohse I, Rasowski J, Cao P, Pintilie M, Do T, Tsao MS, Hill RP and Hedley DW: Targeting hypoxic microenvironment of pancreatic xenografts with the hypoxia-activated prodrug th-302. Oncotarget 7(23): 33571-33580, 2016. PMID: 27248663. DOI: 10.18632/oncotarget.9654

38 Ernsting MJ, Hoang B, Lohse I, Undzys E, Cao P, Do T, Gill B, Pintilie M, Hedley D and Li SD: Targeting of metastasis-promoting tumor-associated fibroblasts and modulation of pancreatic tumorassociated stroma with a carboxymethylcellulose-docetaxel nanoparticle. J Control Release 206: 122-130, 2015. PMID: 25804872. DOI: $10.1016 /$ j.jconrel.2015.03.023

39 Lohse I, Lourenco C, Ibrahimov E, Pintilie M, Tsao MS and Hedley DW: Assessment of hypoxia in the stroma of patientderived pancreatic tumor xenografts. Cancers (Basel) 6(1): 459471, 2014. PMID: 24577243. DOI: 10.3390/cancers6010459

40 Furness JB, Callaghan BP, Rivera LR and Cho HJ: The enteric nervous system and gastrointestinal innervation: Integrated local and central control. Adv Exp Med Biol 817: 39-71, 2014. PMID: 24997029. DOI: 10.1007/978-1-4939-0897-4_3
41 Ceyhan GO, Demir IE, Altintas B, Rauch U, Thiel G, Muller MW, Giese NA, Friess H and Schafer KH: Neural invasion in pancreatic cancer: A mutual tropism between neurons and cancer cells. Biochem Biophys Res Commun 374(3): 442-447, 2008. PMID: 18640096. DOI: 10.1016/j.bbrc.2008.07.035

42 Eibl G and Reber HA: A xenograft nude mouse model for perineural invasion and recurrence in pancreatic cancer. Pancreas 31(3): 258-262, 2005. PMID: 16163058. DOI: 10.1097/01.mpa. $0000175176.40045 .0 f$

43 Gil Z, Cavel O, Kelly K, Brader P, Rein A, Gao SP, Carlson DL, Shah JP, Fong $\mathrm{Y}$ and Wong RJ: Paracrine regulation of pancreatic cancer cell invasion by peripheral nerves. J Natl Cancer Inst 102(2): 107-118, 2010. PMID: 20068194. DOI: 10.1093/jnci/djp456

44 Lohse I, Borgida A, Cao P, Cheung M, Pintilie M, Bianco T, Holter S, Ibrahimov E, Kumareswaran R, Bristow RG, Tsao MS, Gallinger S and Hedley DW: Brca1 and brca2 mutations sensitize to chemotherapy in patient-derived pancreatic cancer xenografts. $\mathrm{Br} \mathrm{J}$ Cancer 113(3): 425-432, 2015. PMID: 26180923. DOI: $10.1038 /$ bjc.2015.220

45 Lohse I, Mason J, Cao PM, Pintilie M, Bray M and Hedley DW: Activity of the novel polo-like kinase 4 inhibitor cfi400945 in pancreatic cancer patient-derived xenografts. Oncotarget 8(2): 3064-3071, 2017. PMID: 27902970. DOI: 10.18632/oncotarget.13619

46 Lohse I, Kumareswaran R, Cao P, Pitcher B, Gallinger S, Bristow RG and Hedley DW: Effects of combined treatment with ionizing radiation and the parp inhibitor olaparib in brca mutant and wild type patient-derived pancreatic cancer xenografts. PLoS One 11(12): e0167272, 2016. PMID: 28033382. DOI: 10.1371/journal.pone.0167272

47 Jing W, McAllister D, Vonderhaar EP, Palen K, Riese MJ, Gershan J, Johnson BD and Dwinell MB: Sting agonist inflames the pancreatic cancer immune microenvironment and reduces tumor burden in mouse models. J Immunother Cancer 7(1): 115, 2019. PMID: 31036082. DOI: 10.1186/s40425-019-0573-5

48 Boldrini L, Cusumano D, Cellini F, Azario L, Mattiucci GC and Valentini V: Online adaptive magnetic resonance guided radiotherapy for pancreatic cancer: State of the art, pearls and pitfalls. Radiat Oncol 14(1): 71, 2019. PMID: 31036034. DOI: 10.1186/s13014-019-1275-3

49 van Mackelenbergh MG, Stroes CI, Spijker R, van Eijck CHJ, Wilmink JW, Bijlsma MF and van Laarhoven HWM: Clinical trials targeting the stroma in pancreatic cancer: A systematic review and meta-analysis. Cancers (Basel) 11(5), 2019. PMID: 31035512. DOI: $10.3390 /$ cancers 11050588

50 Pei Y, Chen L, Huang Y, Wang J, Feng J, Xu M, Chen Y, Song Q, Jiang G, Gu X, Zhang Q, Gao X and Chen J: Sequential targeting tgf-beta signaling and kras mutation increases therapeutic efficacy in pancreatic cancer. Small: e1900631, 2019. PMID: 31033217. DOI: 10.1002/smll.201900631

51 Katsuda M, Miyazawa M, Ojima T, Katanuma A, Hakamada K, Sudo K, Asahara S, Endo I, Ueno M, Hara K, Yamada S, Fujii T, Satoi S, Ioka T, Ohira M, Akahori T, Kitano M, Nagano H, Furukawa $\mathrm{M}$, Adachi $\mathrm{T}$ and Yamaue $\mathrm{H}$ : A double-blind randomized comparative clinical trial to evaluate the safety and efficacy of dendritic cell vaccine loaded with wt 1 peptides (tlp0$001)$ in combination with s-1 in patients with advanced pancreatic cancer refractory to standard chemotherapy. Trials 20(1): 242, 2019. PMID: 31029154. DOI: 10.1186/s13063-019-3332-5 
52 Sisignano $\mathrm{M}$, Baron $\mathrm{R}$, Scholich $\mathrm{K}$ and Geisslinger $\mathrm{G}$ : Mechanism-based treatment for chemotherapy-induced peripheral neuropathic pain. Nat Rev Neurol 10(12): 694-707, 2014. PMID: 25366108. DOI: 10.1038/nrneurol.2014.211

53 Harris DJ: Cancer treatment-induced mucositis pain: Strategies for assessment and management. Ther Clin Risk Manag 2(3): 251258, 2006. PMID: 18360600. DOI: 10.2147/tcrm.2006.2.3.251

54 Avritscher EB, Cooksley CD and Elting LS: Scope and epidemiology of cancer therapy-induced oral and gastrointestinal mucositis. Semin Oncol Nurs 20(1): 3-10, 2004. PMID: 15038511. DOI: 10.1053/j.soncn.2003.10.002

55 Colvin LA: Chemotherapy-induced peripheral neuropathy: Where are we now? Pain 160 (Suppl 1): S1-S10, 2019. PMID: 31008843. DOI: 10.1097/j.pain.0000000000001540

56 Gamelin L, Boisdron-Celle M, Delva R, Guerin-Meyer V, Ifrah N, Morel A and Gamelin E: Prevention of oxaliplatin-related neurotoxicity by calcium and magnesium infusions: A retrospective study of 161 patients receiving oxaliplatin combined with 5-fluorouracil and leucovorin for advanced colorectal cancer. Clin Cancer Res 10(12 Pt 1): 4055-4061, 2004. PMID: 15217938. DOI: 10.1158/1078-0432.CCR-03-0666

57 Meyer L, Patte-Mensah C, Taleb O and Mensah-Nyagan AG: Cellular and functional evidence for a protective action of neurosteroids against vincristine chemotherapy-induced painful neuropathy. Cell Mol Life Sci 67(17): 3017-3034, 2010. PMID: 20431905. DOI: $10.1007 / \mathrm{s} 00018-010-0372-0$

58 Oronsky B, Goyal S, Kim MM, Cabrales P, Lybeck M, Caroen S, Oronsky N, Burbano E, Carter C and Oronsky A: A review of clinical radioprotection and chemoprotection for oral mucositis. Transl Oncol 11(3): 771-778, 2018. PMID: 29698934. DOI: 10.1016/j.tranon.2018.03.014

59 Aprile G, Rihawi K, De Carlo E and Sonis ST: Treatment-related gastrointestinal toxicities and advanced colorectal or pancreatic cancer: A critical update. World J Gastroenterol 21(41): 1179311803, 2015. PMID: 26557003. DOI: 10.3748/wjg.v21.i41.11793

60 Rodriguez-Caballero A, Torres-Lagares D, Robles-Garcia M, Pachon-Ibanez J, Gonzalez-Padilla D and Gutierrez-Perez JL: Cancer treatment-induced oral mucositis: A critical review. Int J Oral Maxillofac Surg 41(2): 225-238, 2012. PMID: 22071451. DOI: $10.1016 /$ j.ijom.2011.10.011

61 McCarthy MW and Walsh TJ: Candidemia in the cancer patient: Diagnosis, treatment, and future directions. Expert Rev Anti Infect Ther 16(11): 849-854, 2018. PMID: 30322269. DOI: $10.1080 / 14787210.2018 .1536546$

62 Fernandes R, Mazzarello S, Majeed H, Smith S, Shorr R, Hutton B, Ibrahim MF, Jacobs C, Ong M and Clemons M: Treatment of taxane acute pain syndrome (taps) in cancer patients receiving taxane-based chemotherapy-a systematic review. Support Care Cancer 24(4): 1583-1594, 2016. PMID: 26386706. DOI: 10.1007/s00520-015-2941-0

63 Donertas B, Unel CC and Erol K: Cannabinoids and agmatine as potential therapeutic alternatives for cisplatin-induced peripheral neuropathy. J Exp Pharmacol 10(19-28, 2018. PMID: 29950907. DOI: $10.2147 /$ JEP.S162059

64 Kanat O, Ertas H and Caner B: Platinum-induced neurotoxicity: A review of possible mechanisms. World J Clin Oncol 8(4): 329335, 2017. PMID: 28848699 DOI: 10.5306/wjco.v8.i4.329

65 Dobosz L, Kaczor M and Stefaniak TJ: Pain in pancreatic cancer: Review of medical and surgical remedies. ANZ J Surg 86(10): 756-761, 2016. PMID: 27111447. DOI: 10.1111/ans.13609
66 Harris DG: Management of pain in advanced disease. Br Med Bull 110(1): 117-128, 2014. PMID: 18443635. DOI: 10.1093/bmb/ldu010

67 Benyamin R, Trescot AM, Datta S, Buenaventura R, Adlaka R, Sehgal N, Glaser SE and Vallejo R: Opioid complications and side effects. Pain Physician 11: S105-120, 2008. PMID: 24393558.

68 Harirforoosh S, Asghar W and Jamali F: Adverse effects of nonsteroidal antiinflammatory drugs: An update of gastrointestinal, cardiovascular and renal complications. J Pharm Pharm Sci 16(5): 821-847, 2013. PMID: 24393558. DOI: 10.18433/j3vw2f

69 Carter GT, Duong V, Ho S, Ngo KC, Greer CL and Weeks DL: Side effects of commonly prescribed analgesic medications. Phys Med Rehabil Clin N Am 25(2): 457-470, 2014. PMID: 24787343. DOI: 10.1016/j.pmr.2014.01.007

70 World Health Organisation. http://www.who.int/cancer/ palliative/painladder/en/ (Last accessed 19/02/2020)

71 Hanks GW, Conno F, Cherny N, Hanna M, Kalso E, McQuay HJ, Mercadante S, Meynadier J, Poulain P, Ripamonti C, Radbruch L, Casas JR, Sawe J, Twycross RG, Ventafridda V and Expert Working Group of the Research Network of the European Association for Palliative C: Morphine and alternative opioids in cancer pain: The eapc recommendations. Br J Cancer 84(5): 587-593, 2001. PMID: 11237376. DOI: 10.1054/bjoc.2001.1680

72 Wolfgang CL, Herman JM, Laheru DA, Klein AP, Erdek MA, Fishman EK and Hruban RH: Recent progress in pancreatic cancer. CA Cancer J Clin 63(5): 318-348, 2013. PMID: 23856911. DOI: $10.3322 /$ caac. 21190

73 Roeckel LA, Le Coz GM, Gaveriaux-Ruff C and Simonin F: Opioid-induced hyperalgesia: Cellular and molecular mechanisms. Neuroscience 338: 160-182, 2016. PMID: 27346146. DOI: 10.1016/j.neuroscience.2016.06.029

74 Varrassi G, Fusco M, Skaper SD, Battelli D, Zis P, Coaccioli S, Pace MC and Paladini A: A pharmacological rationale to reduce the incidence of opioid induced tolerance and hyperalgesia: A review. Pain Ther 7(1): 59-75, 2018. PMID: 29594972. DOI: 10.1007/s40122-018-0094-9

75 Gunduz $\mathrm{OH}$ and Kenis-Coskun O: Ganglion blocks as a treatment of pain: Current perspectives. J Pain Res 10: 28152826, 2017. PMID: 29276402. DOI: $10.2147 / J P R . S 134775$

76 Mercadante S, Catala E, Arcuri E and Casuccio A: Celiac plexus block for pancreatic cancer pain: Factors influencing pain, symptoms and quality of life. J Pain Symptom Manage 26(6): 1140-1147, 2003. PMID: 14654266. DOI: 10.1016/j.jpainsymman.2003.04.004

77 Seicean A: Celiac plexus neurolysis in pancreatic cancer: The endoscopic ultrasound approach. World J Gastroenterol 20(1): 110-117, 2014. PMID: 24415863. DOI: 10.3748/wjg.v20.i1.110

78 Mercadante S: Celiac plexus block versus analgesics in pancreatic cancer pain. Pain 52(2): 187-192, 1993. PMID: 8455966. DOI: 10.1016/0304-3959(93)90130-h

79 Allen PJ, Chou J, Janakos M, Strong VE, Coit DG and Brennan MF: Prospective evaluation of laparoscopic celiac plexus block in patients with unresectable pancreatic adenocarcinoma. Ann Surg Oncol 18(3): 636-641, 2011. PMID: 20953910. DOI: 10.1245/s10434-010-1372-x

80 Wong GY, Schroeder DR, Carns PE, Wilson JL, Martin DP, Kinney MO, Mantilla CB and Warner DO: Effect of neurolytic celiac plexus block on pain relief, quality of life, and survival in patients with unresectable pancreatic cancer: A randomized controlled trial. JAMA 291(9): 1092-1099, 2004. PMID: 14996778. DOI: 10.1001/jama.291.9.1092 
81 Niu L, Wang Y, Yao F, Wei C, Chen Y, Zhang L, Chen J, Li J, Zuo $\mathrm{J}$ and $\mathrm{Xu} \mathrm{K}$ : Alleviating visceral cancer pain in patients with pancreatic cancer using cryoablation and celiac plexus block. Cryobiology 66(2): 105-111, 2013. PMID: 23267876. DOI: 10.1016/j.cryobiol.2012.12.002

82 Lohse I, Wildermuth E and Brothers SP: Naturally occurring compounds as pancreatic cancer therapeutics. Oncotarget 9(83): 35448-35457, 2018. PMID: 30459936. DOI: 10.18632/ oncotarget.26234

83 Kapral M, Wawszczyk J, Jesse K, Paul-Samojedny M, Kusmierz D and Weglarz L: Inositol hexaphosphate inhibits proliferation and induces apoptosis of colon cancer cells by suppressing the akt/mtor signaling pathway. Molecules 22(10), 2017. PMID: 28972559. DOI: 10.3390/molecules22101657

84 Wawszczyk J, Kapral M, Lodowska J, Jesse K, Hollek A and Weglarz L: Antiproliferative effect of inositol hexaphosphate on human skin melanoma cells in vitro. Acta Pol Pharm 72(5): 895900, 2015. PMID: 26665395.

85 Abrams DI: Integrating cannabis into clinical cancer care. Curr Oncol 23(2): S8-S14, 2016. PMID: 27022315. DOI: $10.3747 /$ co.23.3099

$86 \mathrm{Lu} \mathrm{W}$, Dean-Clower E, Doherty-Gilman A and Rosenthal DS: The value of acupuncture in cancer care. Hematol Oncol Clin North Am 22(4): 631-648, viii, 2008. PMID: 18638692. DOI: 10.1016/j.hoc.2008.04.005

87 Choi TY, Lee MS, Kim TH, Zaslawski C and Ernst E: Acupuncture for the treatment of cancer pain: A systematic review of randomised clinical trials. Support Care Cancer 20(6): 1147-1158, 2012. PMID: 22447366. DOI: 10.1007/s00520-012$1432-9$

88 Chen H, Liu TY, Kuai L, Zhu J, Wu CJ and Liu LM: Electroacupuncture treatment for pancreatic cancer pain: A randomized controlled trial. Pancreatology 13(6): 594-597, 2013. PMID: 24280575. DOI: 10.1016/j.pan.2013.10.007
89 Montgomery GH, Schnur JB and Kravits K: Hypnosis for cancer care: Over 200 years young. CA Cancer J Clin 63(1): 31-44, 2013. PMID: 23168491. DOI: 10.3322/caac.21165

90 Denk F, McMahon SB and Tracey I: Pain vulnerability: A neurobiological perspective. Nature Neuroscience 17: 192, 2014. PMID: 24473267. DOI: 10.1038/nn.3628

91 Doehring A, Geisslinger G and Lotsch J: Epigenetics in pain and analgesia: An imminent research field. Eur J Pain 15(1): 11-16, 2011. PMID: 20584621. DOI: 10.1016/j.ejpain.2010.06.004

92 Matsushita Y, Araki K, Omotuyi O, Mukae T and Ueda H: Hdac inhibitors restore c-fibre sensitivity in experimental neuropathic pain model. Br J Pharmacol 170(5): 991-998, 2013. PMID: 24032674. DOI: $10.1111 /$ bph.12366

93 Niederberger E, Resch E, Parnham MJ and Geisslinger G: Drugging the pain epigenome. Nature Reviews Neurology 13: 434, 2017. PMID: 28548108. DOI: 10.1038/nrneurol.2017.68

94 Alvarado S, Tajerian M, Suderman M, Machnes Z, Pierfelice S, Millecamps M, Stone LS and Szyf M: An epigenetic hypothesis for the genomic memory of pain. Front Cell Neurosci 9: 88, 2015. PMID: 25852480. DOI: 10.3389/fncel.2015.00088

95 Denk F, Crow M, Didangelos A, Lopes DM and McMahon SB: Persistent alterations in microglial enhancers in a model of chronic pain. Cell Rep 15(8): 1771-1781, 2016. PMID: 27184839. DOI: $10.1016 /$ j.celrep.2016.04.063
Received January 16, 2020

Revised February 18, 2020

Accepted February 19, 2020 